\title{
Factors Forming Public Appraisal on Service Quality of Sukabumi Municipal Water Supply Company (PDAM)
}

\author{
Ike Rachmawati ${ }^{1}$, Ikeu Kania ${ }^{2}$, Ujuh Juhana ${ }^{3}$ \\ ${ }^{1}$ Faculty of Administration Sciences and Humanities, Universitas Muhammadiyah Sukabumi, Indonesia \\ ${ }^{2}$ Faculty of Politics and Social Sciences, Universitas Garut, Indonesia \\ ${ }^{3}$ Faculty of Law, Universitas Muhammadiyah Sukabumi, Indonesia \\ Correspondence: Ike Rachmawati, Faculty of Administration Sciences and Humanities, Universitas Muhammadiyah \\ Sukabumi, Indonesia
}

Received: November 10, 2018

Accepted: December 11, 2018

Online Published: December 22, 2018

doi:10.11114/ijlpa.v1i2.3760

URL: https://doi.org/10.11114/ijlpa.v1i2.3760

\begin{abstract}
The people of Sukabumi city as the customers of drinking water complain that the Sukabumi Municipal Water Supply Company (PDAM) service is still not optimal. Therefore, this study aims to find out the factors forming public appraisal of PDAM service quality. Using a quantitative approach, the survey was conducted toward the customers of Sukabumi Municipal Water Supply Company (PDAM). A total of 120 respondents were selected by simple random sampling method which then analyzed using confirmatory factor analysis. The service quality variables consisting of tangible, reliability, responsiveness, assurance and empathy are broken down into 31 indicators. The result shows that 4 factors out of 31 indicators tested were influential in forming public appraisal on service quality of Sukabumi Municipal Water Supply Company (PDAM). These factors include accuracy (at an eigen score of 10.671), politeness (at eigen score of 2.021), response speed (at eigen score of 1.646) and technological capability (at eigen score of 1.333).
\end{abstract}

Keywords: service quality, confirmatory factor analysis, PDAM of Sukabumi city

\section{Introduction}

Public service in a narrow sense is an act of providing goods and services to the public by the government in order to fulfill its responsibilities to the society, whether it is provided directly or through partnerships with private and public parties. This concept emphasizes how public services are successfully delivered through a healthy "delivery system" in order to provide the best goods and services for the society.

For the citizens, improving public services is very important to be a priority considering that the citizens have been the victims of poor public service practices as described above. Almost in every aspect of life from birth to death, citizens have to face bad government services. To improve the service quality, a comprehensive policy is needed which includes mindset changes, improvements in service system and procedures, and a review of the organizational structure responsible for service delivery.

One of many public services performed by the local govenment related to the lives of many people is water. It is managed by the Municipal Water Supply Company of PDAM. Clean water management is very important and it is the most needed thing in the daily life of society. In the 1945 Constitution, Article 33, paragraph 3, it is explained that, "Earth and water and the natural resources contained therein are controlled by the state and used optimally for the welfare of the people." Since water management is very important, it becomes a major challenge for future development. Focusing on water sources does not mean reducing the importance of other sectors. In fact, it is even necessary to integrate it with other sectors in schemes. Some water-related fields are such as housing, tourism, industry.

Based on the Decree (SK) of Sukabumi mayor No. 89 / kpts / 1966, it is mentioned that the Municipal Water Supply Company (PDAM) of Tirta Bumi Wibawa Sukabumi is a local business unit of Sukabumi City government whose management is administratively still using the budget of the local Government. Based on a Circular Letter issued by the Minister of Home Affairs concerning the Sukabumi City Council's Decree on the Implementation of an independent corporate management administration on 31 July 1971 No. 8/10/1971 and on 28 August 1975 No. 3 / kpts / PD / 1975, thus the Municipal Water Supply Company (PDAM) of Tirta Bumi Wibawa Sukabumi has officially become an 
independent company as well as a legal entity.

The Municipal Water Supply Company (PDAM) of Tirta Bumi Wibawa Sukabumi is one of the Local government Owned Enterprises (BUMD) established based on Local Regulation No. 3/PD/1975. The Municipal Water Supply Company (PDAM) of Tirta Bumi Wibawa Sukabumi is managed under the Local Government Regulation Number 5 of 2002 concerning Municipal Water Supply Company (PDAM) of Tirta Bumi Wibawa Sukabumi with the purposes and objectives such as:

1. To provide clean water services;

2. To assist and encourage regional economic growth;

3. To become one of the local income sources of Sukabumi City govenment (PAD).

Mayor of Sukabumi City Regulation No. 03 of 2013 and Board of Directors Decree No. SK. 690/031/Kep.Dir/ PDAM / IX / 2012 mention that the Municipal Water Supply Company (PDAM) of Tirta Bumi Wibawa Sukabumi has 4 groups of customers; group one consists of general social and special social, group two consists of non-commercial type A, governmental institutions, and non-commercial type B, group three consists of non-commercial type $\mathrm{C}$, small trading, and small industries, group four consists of large commercial and large industries.

Based on the results of interviews, observations and data obtained by the researchers, it is found that there are issues in the division of customer Relations of Sukabumi municipal water supply company (PDAM) associated with customer unsatisfactions on the services provided as indicated below:

1. Customers complain that they do not get the water they expect, in fact they have regularly paid monthly dues;

2. Customers complain that the service pipes are often leaked which certainly disrupts them in using the water, thus the water cannot be distributed or streamed;

3. Customers complain because the water is not feasible to use. Water from the municipal water supply company (PDAM) of Sukabumi is dirty and smelly, so it is not feasible to be consumed and used for bathing.

Based on the description above, the researchers become interested to conduct a research with the title Factors Forming Public Appraisal on the Service Quality of Sukabumi Municipal Water Supply Company (PDAM).

\section{Literature Review}

Quality is often equated with products or services that have characteristics (Burböck, 2014). The difference between quality characteristics, as a factor is helpful (Zollondz, 2006). Service quality is an important area for academics because of its relevance to the service and therefore many researchers have tried to develop models to measure it, although some claim it is difficult to measure because of its intangible difficulty (Eshghi, et.al. 2008). Parasuraman, et al. (1985) announced a new instrument to measure quality service called SERVQUAL, consisting of two main terms: Service and Quality. The SERVQUAL model is a multi-item scale model used to measure the quality of an organization's services in any of its services (Pollitt, 2002). In practice, the instrument is given twice in various forms, first to measure expectations and second to measure perception.

There are five dimensions of service quality dimension based on Parasuraman, et al., (1988) among others:

1) Tangibility, relating to physical, facilities, and employee skills;

2) Reliability is the ability to perform services consistently and accurately;

3) Responsiveness is the willingness of employees to assist customers in solving problems;

4) Warranties are sufficient knowledge of employees of employees' self-confidence;

5) Empathy is attributed to the way organizations pay attention to their customers.

The provision of public services is the main task of the government. Usually citizens have played a passive role as recipients of public service standards without being asked to provide feedback on the goods and services they receive from the government. Elections are considered as an adequate mechanism for expressing their perceptions and satisfaction with the public services provided (Martinović et al., 2017). The public sector is established to serve the community so that the quality of service provided is determined by the satisfaction or experience of the community, amidst the demands of various people, the administrative institutions of service can satisfy people only with innovation and continuous improvement of service quality (Hsiao \& Lin, 2008). The use of various measures of service quality in the private sector as an important indicator of organizational performance and customer satisfaction can be widely accepted and broad. However, it is different from measuring customer satisfaction on public services (Wisniewski, 2010) (Ramdhani \& Ramdhani, 2017). With the mind-set of "Customer-oriented services", customer value can be an important administrative basis, directly interact with the community, gather customer-related information, and thereby 
improve public service products and services (Chiang, 1999).

Wisniewski (2007) applies SERVQUAL to public libraries owned by the government. Pollit (2002) recognizes that the reform of New Public Management in the world is supported by several common goals and features, including effective, efficient and responsive production services by public services to its customers, and a commitment to continuously improve the quality and empowerment of staff to innovate. Ocampo, et al. (2017) combine SERVQUAL with Analytical Hierarchy Process (AHP) in evaluating the quality of service of government agencies in the Philippines. Brahmbhatt \& Panelia (2008) use the SERVQUAL model in evaluating the quality of service and customer satisfaction of private banks, state banks and foreign banks. Local community satisfaction has also been measured in research on public service of Dubrovnik city in Krosia (Martinović, Pavlić, \& Tolić, 2017). Factor analysis confirms the suitability of the instrument in the study (Iyikal \& Celebi, 2016) regarding the quality of service performed by the public company TRNC. Mokhtar et al. (2013) said that measuring public sector services at Dental Hospital Punjab Lahore using SERVQUAL.

\section{Methodology}

The research applies qualitative design with explanatory survey that explains and analyzes how big communication influence toward PDAM of Sukabumi city water supply customer service quality whether partially or simultaneous. The basic research consideration was conducted by qualitative design because (1) it searched influence between $\mathrm{X}$ variable and $\mathrm{Y}$ variable; (2) $\mathrm{X}$ variable (communication strategy) and $\mathrm{Y}$ variable (PDAM water supply customer service quality could be measured qualitatively based on indicators from each dimension by using applied statistics; and (3) it filed hypothesis on research question as reference in collecting empirical data or data verification suitable with research aim.

To obtain data that is used as size of influnece from each research variable, so that it is conducted causality test from communication factor strategies on dependent variable $(\mathrm{X})$ and independent variable $(\mathrm{Y})$. Therefore, data analysis applies regression linier multiple which is continued by applying path analysis. With path analysis will be known how big variable $\mathrm{X}$ influence toward $\mathrm{Y}$ whether partially or simultaneous.

Furthermore, research object is society group of PDAM water supply customer. As control information is done confirmation/interview to PDAM Sukabumi city officer that is water supply customer service quality section in customer relation. Research population is PDAM Sukabumi city. The technique applies simple random sampling technique because population is taken randomly without considering strata in such population (Sugiono, 2012:93). Research sample applies 120 respondents. From sample total is allocated based on each region distribution. A total of 120 respondents were selected by simple random sampling method which then analyzed using confirmatory factor analysis. The service quality variables consisting of tangible, reliability, responsiveness, assurance and empathy were broken down into 31 indicators.

Researchers apply likert scale that has gradation from positive gradation to negative gradation. Research instrument is tested through validation and reliability by applying pearson product moment correlation formula. Instrument reliability is done by consistency internal with split half technique that is analyzed by using spearman brown formula. Correlation coefficient which is applied is pearson product moment correlation (Sugiono, 2012: 212) as follows:

$$
\mathrm{rxy}=\frac{n \sum x_{\mathrm{i}} y_{\mathrm{i}}-\left(\sum x_{\mathrm{i}}\right)\left(\sum y_{\mathrm{i}}\right)}{\sqrt{\left\{n \sum x_{\mathrm{i}}^{2}-\left(\sum x_{\mathrm{i}}\right)^{2}\right\}\left\{n \sum y_{\mathrm{i}}^{2}-\left(\sum y_{\mathrm{i}}\right)^{2}\right\}}}
$$

Determination coefficient is applied to know the influence between $\mathrm{X}$ variable toward $\mathrm{Y}$ variable that can be determined by determination coefficient formula as follows.

$$
\mathrm{KD}=\mathrm{r}^{2} \times 100 \%
$$

Remark:

$\mathrm{KD}=$ determination coefficient score

$\mathrm{r}=$ correlation coefficient score

\section{Hypothesis Test}

Correlation coefficient mean test applies $t$ test formula as follows.

Test criteria:

$$
t=\frac{r \sqrt{n-2}}{\sqrt{1-r^{2}}}
$$

$\mathrm{H}_{0}$ accept, if $\mathrm{t}_{\text {- }}$ count $<\mathrm{t}_{(1-0,05 / 2)(\mathrm{db})}$ 
$\mathrm{H}_{0}$ refuse, if $\mathrm{t}_{\text {- }{ }_{\text {count }}}>\mathrm{t}_{(1-0,05 / 2)(\mathrm{db})}$

Research hypothesis is accepted if $\mathrm{H}_{0}$ is refused, in real scale $\alpha=0,05$ and independent degree $(\mathrm{db})=\mathrm{n}-2$.

Research Framework (Fishbone Diagram)

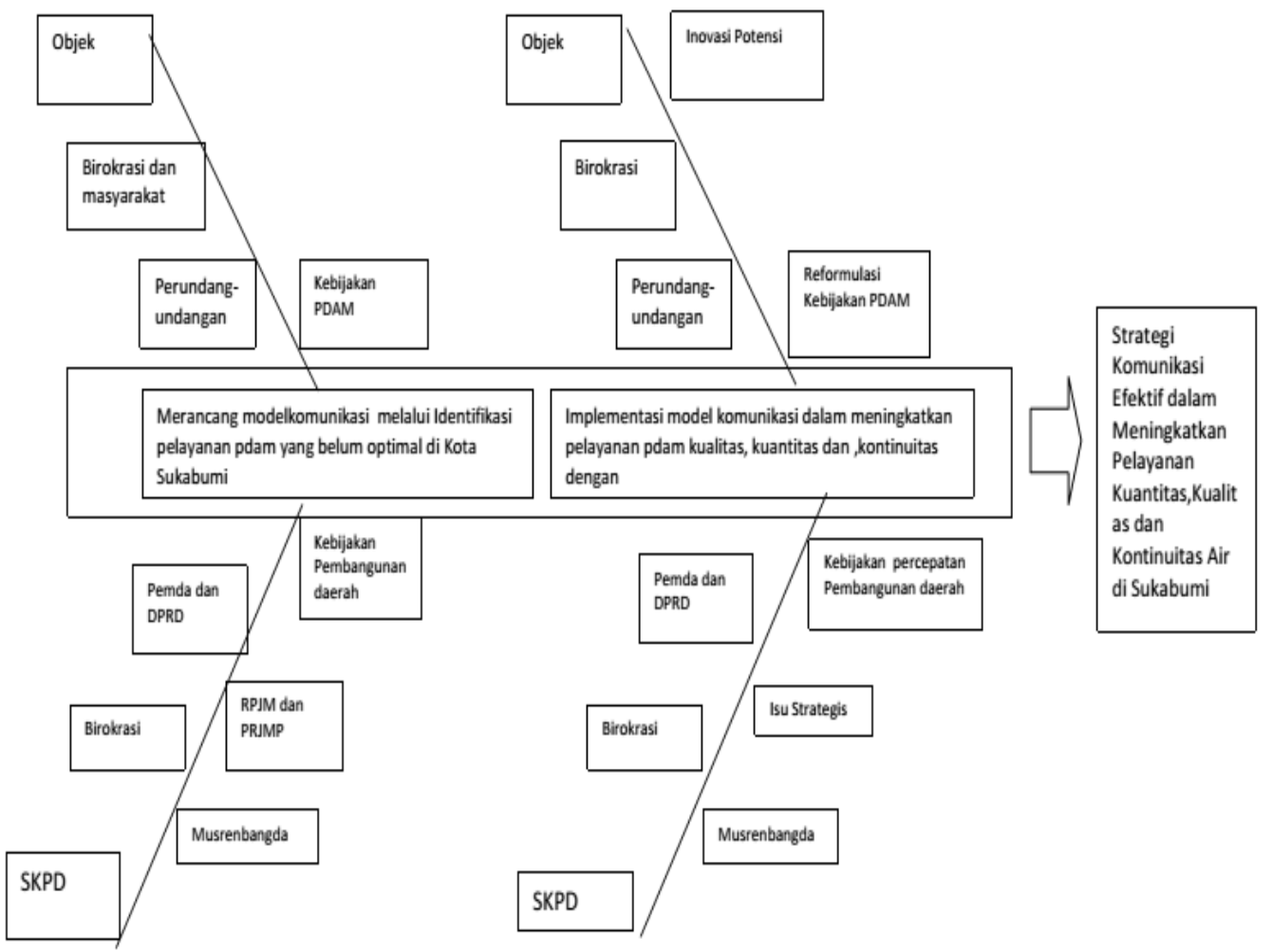

\section{Result and Discussion}

The result of factor analysis using SPSS is as follows in table 1

Table 1. KMO and Bartlett's Test

\begin{tabular}{lll}
\hline Kaiser-Meyer-Olkin Measure of Sampling Adequacy. & \multicolumn{2}{c}{898} \\
Bartlett's Test of Sphericity & Approx. Chi-Square & 1923.328 \\
& df & 276 \\
& Sig. & .000 \\
\hline
\end{tabular}

The result shows that the value of KMO \& Bartlett's Test is 0.898 with a significance of 0.000 , in other words, the existing variables and samples are sufficient for further analysis. While in the anti-image correlation, the value below 0.500 is not obtained. Thus, the test can be processed to the next stage. From the Total Variance Explained results, it appears that only four factors are formed because the Eigenvalue is above 1. Once it is known that the previous variables are formed into four optimal factors, then, the next step is to determine what variable will enter which factor.

Based on the results of factor analysis, then the 24 factors are summarized into 4 formed factors in which the loading value criterion is only for the variables of $>0.50$ while those less than that is negligible. Table 2 shows the loading values of each factor: 
Table 2. Loading Values of Each Factor

\begin{tabular}{|c|c|c|c|c|}
\hline & \multicolumn{4}{|c|}{ Component } \\
\hline & 1 & 2 & 3 & 4 \\
\hline Employee appearance & -.092 & .758 & .188 & .182 \\
\hline Public comfort & .322 & .405 & .326 & .211 \\
\hline Ease of administration & .539 & .367 & .386 & .075 \\
\hline Ease of access & .495 & .553 & .090 & .048 \\
\hline Employee discipline & .393 & .562 & .289 & .222 \\
\hline Use of tools & .246 & .264 & -.084 & .699 \\
\hline Accuracy & .204 & .303 & .524 & .399 \\
\hline Service standard & .464 & .174 & .182 & .641 \\
\hline Employee capability & .141 & .279 & .155 & .739 \\
\hline Employee skills & .621 & .131 & .230 & .480 \\
\hline Employee response & .035 & .353 & .658 & .216 \\
\hline Speed & .358 & .097 & .821 & .102 \\
\hline Accuracy in processing documents & .364 & .224 & .781 & .117 \\
\hline Responding to customers & .726 & .205 & .437 & .121 \\
\hline Responding to criticism\&suggestions. & .536 & .402 & .473 & .050 \\
\hline Punctuality & .792 & .189 & .175 & .072 \\
\hline Cost guarantee & .713 & -.064 & .059 & .401 \\
\hline Legal guarantee & .192 & -.116 & .346 & .666 \\
\hline Certainty of service charge. & .628 & .076 & .180 & .385 \\
\hline Giving priority to customers. & .699 & .199 & .209 & .245 \\
\hline Friendliness of service & .564 & .524 & .095 & .172 \\
\hline Politeness. & .232 & .763 & .203 & .300 \\
\hline Non-discrimination. & .294 & .728 & .131 & -.071 \\
\hline Appreciating customers. & -.054 & .570 & .361 & .495 \\
\hline
\end{tabular}

Extraction Method: Principal Component Analysis

From the results of factor analysis test, the newly formed factors can be seen from the following Table3.

Table 3. Names of New Factors and Loading Factors

\begin{tabular}{cclc}
\hline No & \multicolumn{1}{c}{ Names of Loading Factors } & Names of New Factors \\
\hline 1. & a. & Ease of administration & \\
& b. & Employee skills & \\
& c. & Responding to customers \\
& d. & Responding to criticism and suggestions \\
& e. & Punctuality \\
& f. & Cost warranty \\
& g. & Certainty of cost \\
& h. & Giving priority to customers & \\
i. & Friendliness of service & Politeness \\
\hline 2. & a. & Employee appearance & \\
& b. & Public comfort &
\end{tabular}


c. Ease of access

d. Employee Discipline

e. No discrimination

f. Appreciating customers

3. a. Employee accuracy

b. Employee response

c. Employee speed

d. Accuracy in processing documents

4. a. Use of tools

b. Service standard

c. Employees capability

d. Legal guarantee

e. Politeness

From the analysis of 24 variables, four new factors are formed; accuracy, politeness, speed of response, and proficiency in using technology.

The research gives contribution for administration science development especially to public service quality and the research benefit gives infromation, as consideration to recommend Sukabumi Municipal Water Supply Company (PDAM) in the effort of increasing service quality of clean water and drinking water need in Sukabumi Municipality.

\section{Conclusion and Suggestion}

From the analysis, it can be concluded as follows:

1. Of the twenty-four variables studied, through the process of factoring they can be summarized or reduced into four factors.

2. The formed factors are:

a) Accuracy factor which includes the variables of ease of administration, employee skills, responding to customers, responding to criticism and suggestion, punctuality, cost guarantee, cost certainty, customer priority, and friendliness of service.

b) Politeness factor which includes the variables of employee performance, public convenience, ease of access, employee discipline, non-discrimination, and appreciating customers.

c) Response speed factor which includes the variables of employee accuracy, employee response, employee speed, and accuracy in processing documents.

Proficiency in using technology factor which includes the variables of use of tool variable, service standards, employee skills, legal guarantees, and courtesy.

\section{References}

Brahmbhatt, M., \& Panelia, D. (2008). An Assessment of Service Quality inBanks. Global Management Review, 2(4), 37-41.

Burböck, B. (2014). Prospect Theory and Servqual. Management, 9(2), 155-168.

Chiang, M. C. (1999). Government reconstruction and customer-oriented service mindset. National Central Library Taiwan Branch Library Journal, 6(1), 1-17.

Eshghi, A., Roy, S. K., \& Ganguli, S. (2008). Service quality and customer satisfaction: An empirical investigation in Indian mobile Telecommunications services. Marketing Management Journal, 18(2), 119-144.

Hsiao, C.-T., \& Lin, J.-S. (2008). A Study of Service Quality in public Sector. International Journal of Electronic Business Management, 6(1), 29-37.

Iyikal, O. C., \& Celebi, A. (2016). Investigating a Quality of Services in the Public Sector: Evidence from Nothern 
Cyprus . Journal of Economic and Social Development, 3(2), 1-15.

Martinović, M., Pavlić, I., \& Tolić, M. Š. (2017). Measurement of Local Public Services Quality Using Servqual: The Case of Dubrovik . EKON. MISAO I PRAKSA DBK. GOD , XXVI(2), 593-610.

Mukhtar, H., Saeed, A., \& Ata, G. (2013). Measuring service quality in Public Sector using SERVQUAL: A case of Punjab Dental Hospital, Lahore. Research on Humanities and Social Sciences, 3(22), 65-71.

Ocampo, L., Alinsub, J., Casul, R. A., Enquig, G., Luar, M., Panuncillon, N., . . Ocampo, C. O. (2017). Public service quality evaluation with SERVQUAL and AHP-TOPSIS: A case of Philippine government agencies. Socio-Economic Planning Sciences. https://doi.org/10.1016/j.seps.2017.12.002

Parasuraman, A., Berry, L., \& Zeithaml, V. (1985). A Conceptual Model of Service Quality and Its Implications for Future Research. Journal of Marketing, 49(4), 41-50. https://doi.org/10.1177/002224298504900403

Parasuraman, A., Zeithaml, V. A., \& Berry, L. L. (1988). SERVQUAL: a multiple-item scale for measuring consumer perceptions of service quality. Journal of Retailing, 12-40.

Pollitt, C. (2002). The New Public Management in international perspectives. An analysis of impacts and effects. In K. McLaughlin, S. Osborne, \& E. Ferlie, New Public management: Current Trends and Future Prospects, (pp. 274-292).

Ramdhani, A., \& Ramdhani, M. A. (2017). Konsep Umum Pelaksanaan Kebijakan Publik. Jurnal Publik, 11(1), 1-12.

Sudjana. 2002. Metode Statistika. Bandung: Tarsito.

Sugiono. 2012. Metode Penelitian Bisnis. Bandung: Alfabeta.

Wisniewski, M. (2010). Measuring service quality in the public sector: The potential for SERVQUAL. Total Quality Management, 7(4), 357-366. https://doi.org/10.1080/09544129650034710

Zollondz, H. (2006). Grundlagen Qualitätsmanagement. München: Oldenbourg. https://doi.org/10.1524/9783486592511

\section{Copyrights}

Copyright for this article is retained by the author(s), with first publication rights granted to the journal.

This is an open-access article distributed under the terms and conditions of the Creative Commons Attribution License which permits unrestricted use, distribution, and reproduction in any medium, provided the original work is properly cited. 